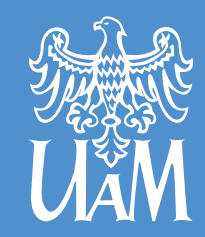

ADAM MICKIEWICZ

UNIVERSITY

POZNAN̂

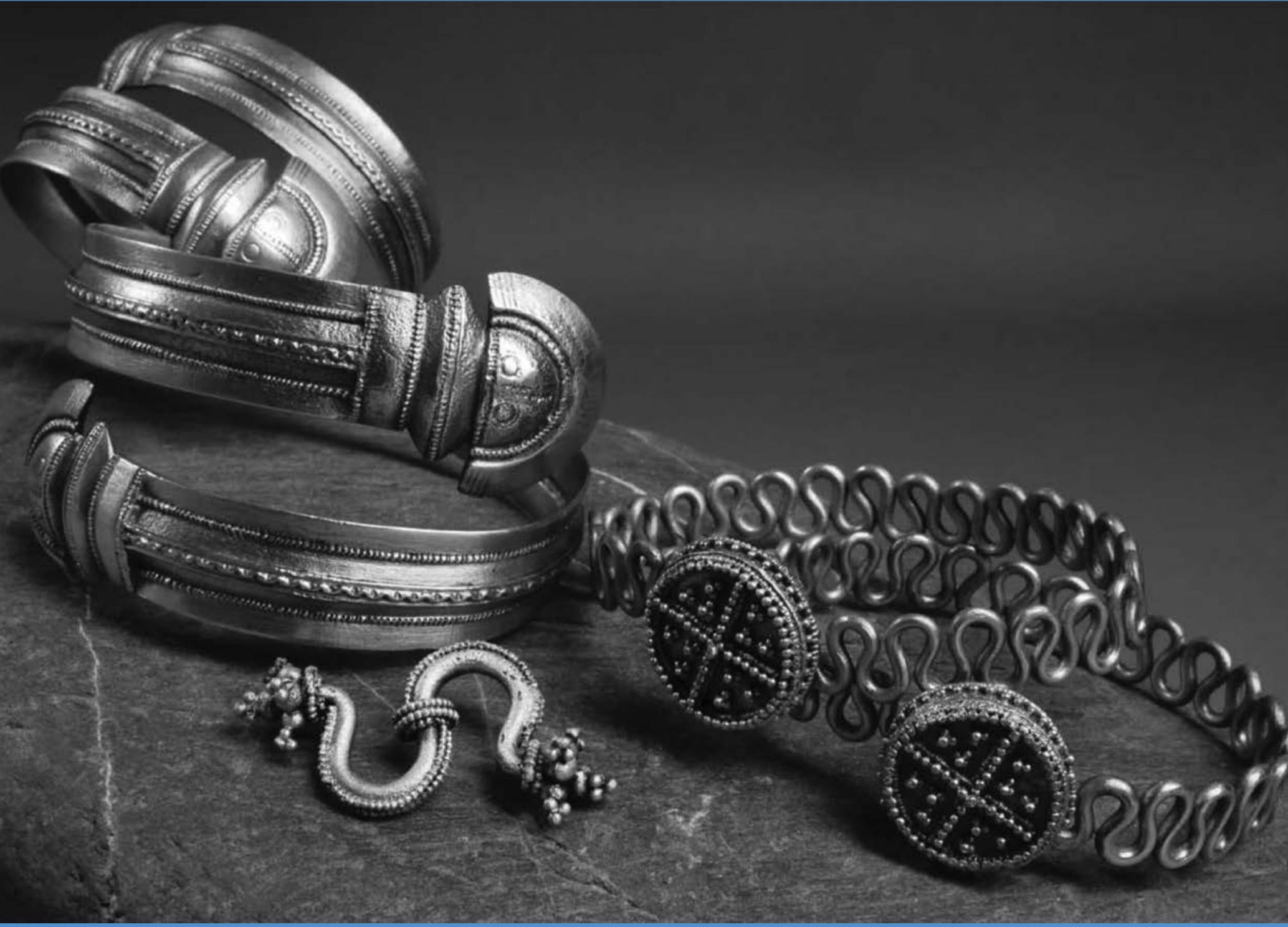

\title{
Treasures of Time
}

Research of the Faculty of Archaeology of Adam Mickiewicz University in Poznań 


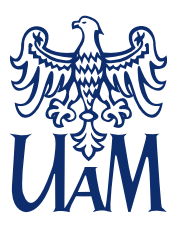

ADAM MICKIEWICZ

UNIVERSITY

POZNAŃ

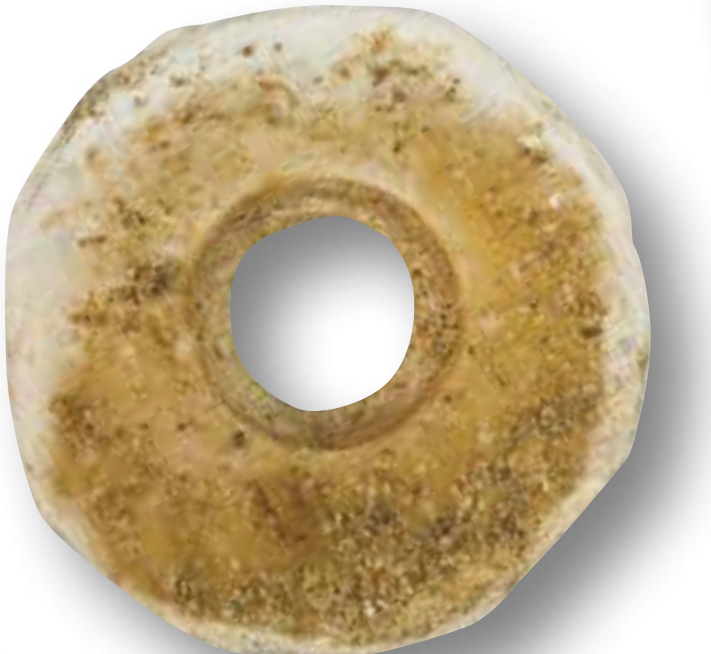

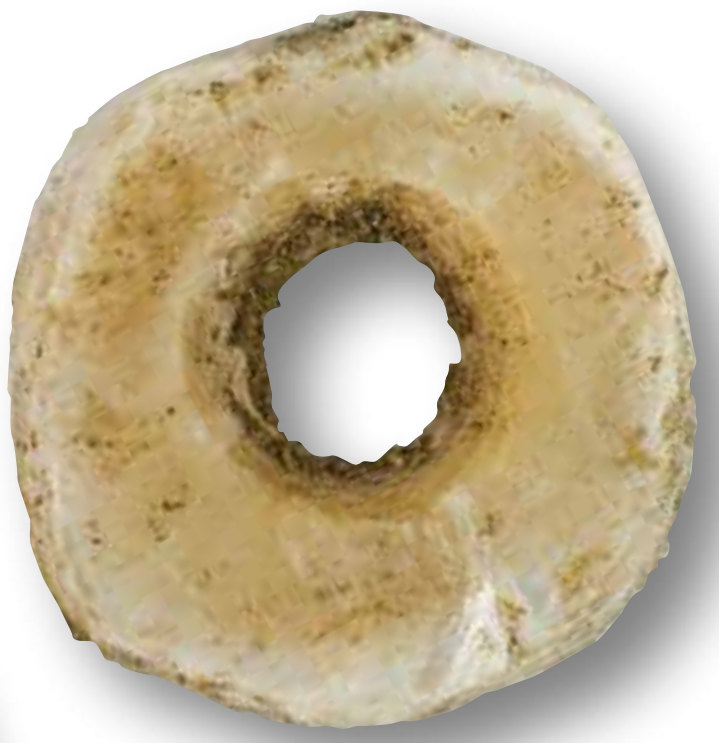
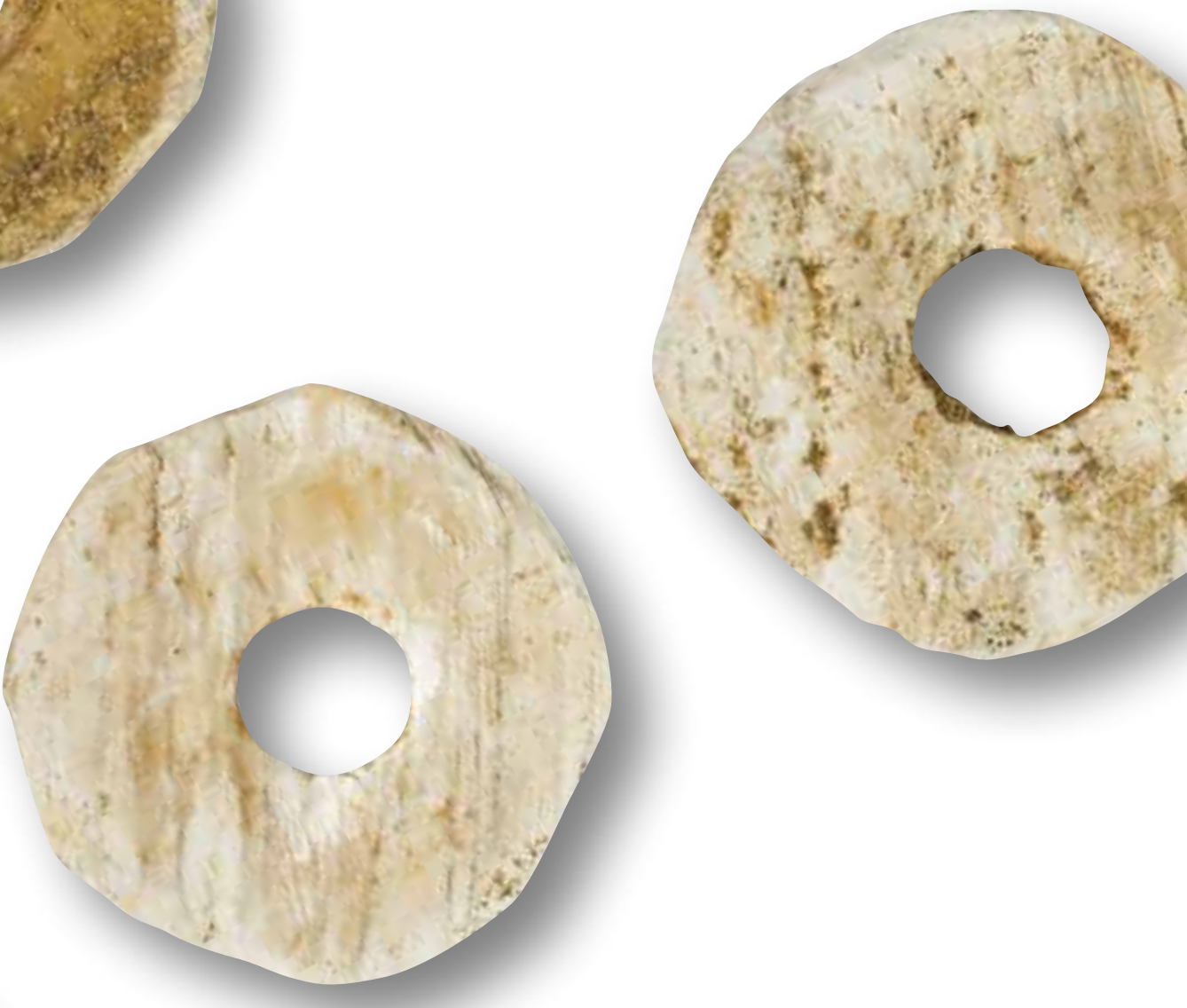

\section{Treasures of Time}

Research of the Faculty of Archaeology of Adam Mickiewicz University in Poznań
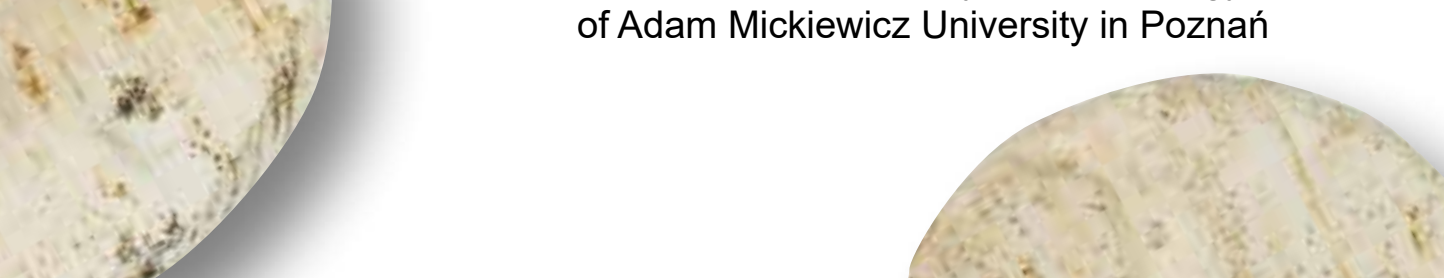
Copyright $\odot$ by the Authors and Faculty of Archaeology, Adam Mickiewicz University, Poznań 2021

Editor

Danuta Żurkiewicz, danuta@amu.edu.pl

Editorial Committee

Marcin Ignaczak, Przemysław Makarowicz,

Andrzej Michałowski, Anna Skowronek, Jacek Wierzbicki

English proofreading

Sarah Martini, Grażyna Piątkowska, Asta Rand

Technical Editor and Layout

kreomania Justyna Kozłowska, Hanna Kossak-Nowicień

Cover

Mirosław, Greater Poland Voivodeship, site 37. Part of the burial equipment. Photo: K. Zisopulu. Cover design: Justyna Kozłowska

Reviewers: Artur Błażejewski, Jacek Górski

Editor's Address

Faculty of Archaeology, Adam Mickiewicz University in Poznan,

Uniwersytetu Poznańskiego 7, 61-614 Poznań, Poland

\section{ISBN 978-83-946591-9-6}

DOI: 10.14746/WA.2021.1.978-83-946591-9-6

The Volume is available online at the Adam Mickiewicz University Repository (AMUR): https://repozytorium.amu.edu.pl/

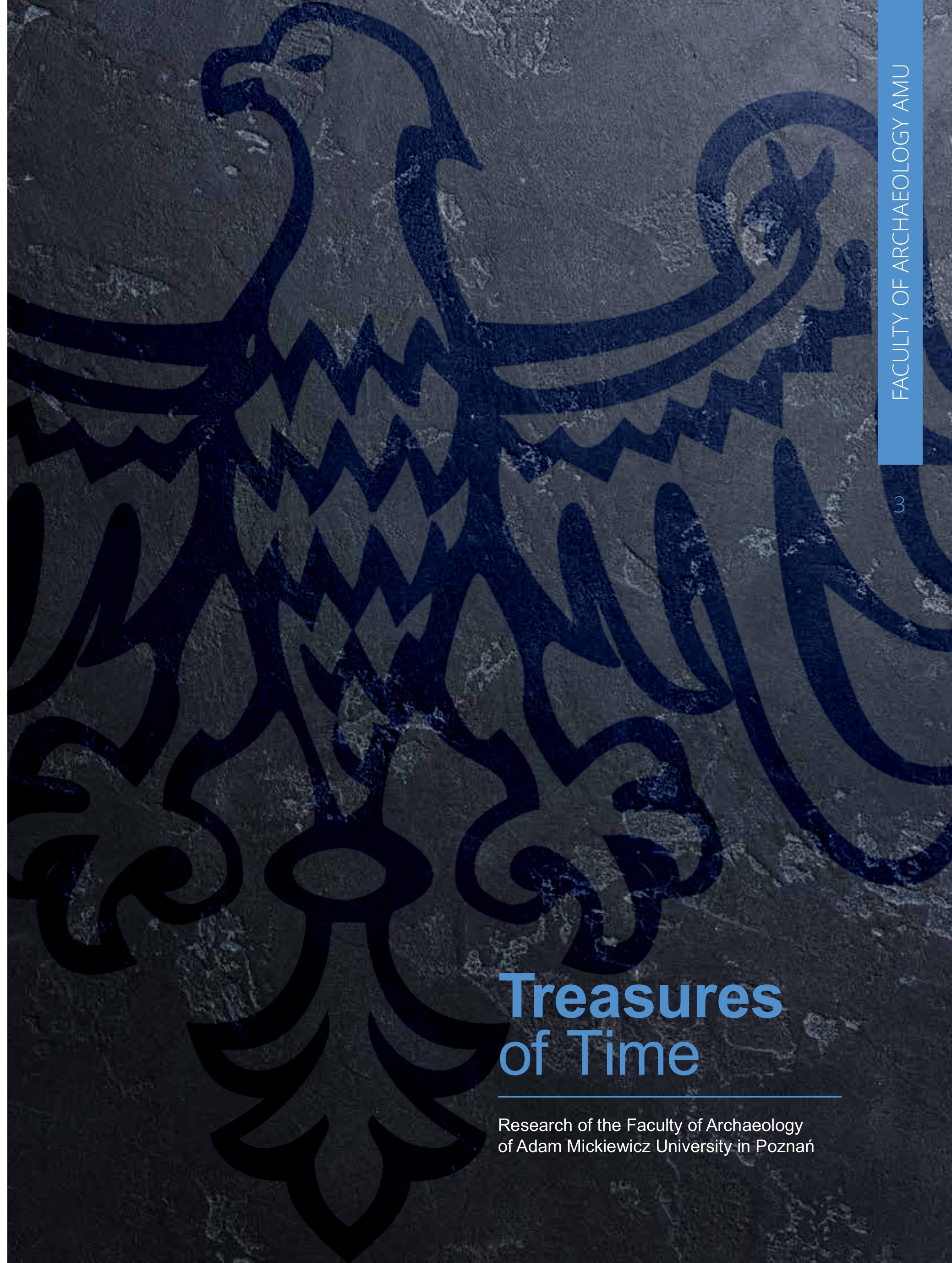




\section{Contents}

Andrzej Michałowski, Danuta Żurkiewicz

Introduction

1. Patrycja Filipowicz, Katarzyna Harabasz, Jẹdrzej Hordecki, Karolina Joka, Arkadiusz Marciniak Late Neolithic and post-Neolithic settlements and burial grounds in the TPC Area at Çatalhöyük:

The research project of the archaeological team of Adam Mickiewicz University in Poznan

2. Danuta Minta-Tworzowska

eritage regained: results of rescue excavations in the Land of Cracow

3. Danuta Żurkieiwcz

Lost and found: The Funnel Beaker culture's 'megalithic tombs' in the cultural

and natural landscape of Greater Poland

Aleksandr Diachenko, Iwona Sobkowiak-Tabaka

Tatarysky: Small-scale insight on large-scale questions

5. Aleksander Kośko Marzena Szmyt

Late Neolithic Hilltop Communities in Central Kujawy

6. Aleksander Kośko, Piotr Włodarczak, Danuta Żurkiewicz

Between the East and the West of Europe: The Eneolithic and the Beginning of the Bronze Age

in Light of Studies on Bio-Cultural Borderlands

7. Stelios Andreou, Maria Pappa, Janusz Czebreszuk, Konstantinos Vouvalidis, George Syrides,

In the Valley of Anthemous ... (Northern Greece)

8. Ewa Bugaj

Some Remarks on the Problems of Researching Art in Archaeology using the Examples

of Prehistoric Figurines and Attic Geometric Pottery

9. Przemysław Makarowicz, Jan Romaniszyn, Vitalii Rud

The barrow culture of the Upper Dniester Basin in the $3^{\text {rd }}$ and $2^{\text {nd }}$ millennia BC:

The Polish-Ukrainian research projects

10. Mateusz Jaeger, Robert Staniuk, Sofia Filatova
Kakucs-Turján: a multi-layered settlement in Central Hungary

11. Jakub Niebieszczański, Mariusz Gałka, Iwona Hildebrandt-Radke, Monika Karpińska-Kołaczek,

12. Rafał Kolinski

13. Rafał Koliński, Xenia Kolińska

From the cradle to the grave

14. Janusz Czebreszuk

Metallurgy in the Early Bronze defensive settlement in Bruszczewo, site 5, Śmigiel commune, Kościan district: One more step on the way to the synthesis
15. Paulina Suchowska-Ducke

Aspects of ancient warfare: Multidisciplinary research on war and warriors

Migration and kinship in East-Central Europe in the $1^{\text {st }}$ half of the $2^{\text {nd }}$ millennium BC

17. Andrzej Michałowski, Milena Teska, Marta Krzyżanowska, Patrycja Kaczmarska, Mateusz Frankiewicz,

About the 'interim' or discovering the depths of the pre-Roman Iron Age

18. Ewa Bugaj

Some Remarks on the Problems of Art Research in Archaeology using the Example of Greek and Roman Sculpture

19. Andrzej Michałowski

arrows in the Skirts of the Forest. Excavation of a Wielbark culture cemetery

Birostaw 37, Ujście commune, Piła district, Greater Poland Voivodeship

20. Marcin Danielewski

The stronghold in Grzybowo and its settlement base in the context of in-depth interdisciplinary research

21. Hanna Kóčka-Krenz, Olga Antowska-Gorączniak, Andrzej Sikorsk

Poznan in the early Middle Age

22. Marcin Ignaczak, Andrzej Sikorski, Artur Debski, Mateusz Sikora

Research on Kolegiacki Square in Poznań (St. Mary Magdalene Parish Collegiate Church)

23. Olga Antowska-Gorączniak

Archaeological research of the Gothic Church of the Blessed Virgin Mary

on the island of Ostrów Tumski, Poznan

24. Michał Krueger

Polish archaeological research in the lberian Peninsula

25. Andrzej Rozwadowski

Rock art as a source of contemporary cultural identity:

a Siberian-Canadian Comparative Study

26. Danuta Minta-Tworzowska

re we where we wanted to be? Modernist tendencies versus the postmodern reality

Mick. Some remarks on the methodology of archaeologists

27. Aldona Kurzawska, Iwona Sobkowiak-Tabaka

of Archaeology Adam Mickiewicz University in Poznań 
Treasures of Time:

Research of the Faculty of Archaeology

of Adam Mickiewicz University in Poznań

\section{Introduction}

In 2019, archaeology at the Adam Mickiewicz University in Poznan celebrated its honourable $100^{\text {th }}$ anniversary! The establishment of archaeology at this university was associated with the strong influence of the authority of Prof. Józef Kostrzewski and a succession of eminent scholars, many of whom we today call Masters.

The year 2019 was a real breakthrough. We started the second century of existence within the Alma Mater Posnaniensis with a new structural independence and quality that the academic archaeology of Poznan had not yet known for its one hundred years of existence. This change, the formation of the first Polish Faculty of Archaeology, has opened new chances and possibilities of which we are now taking advantage.

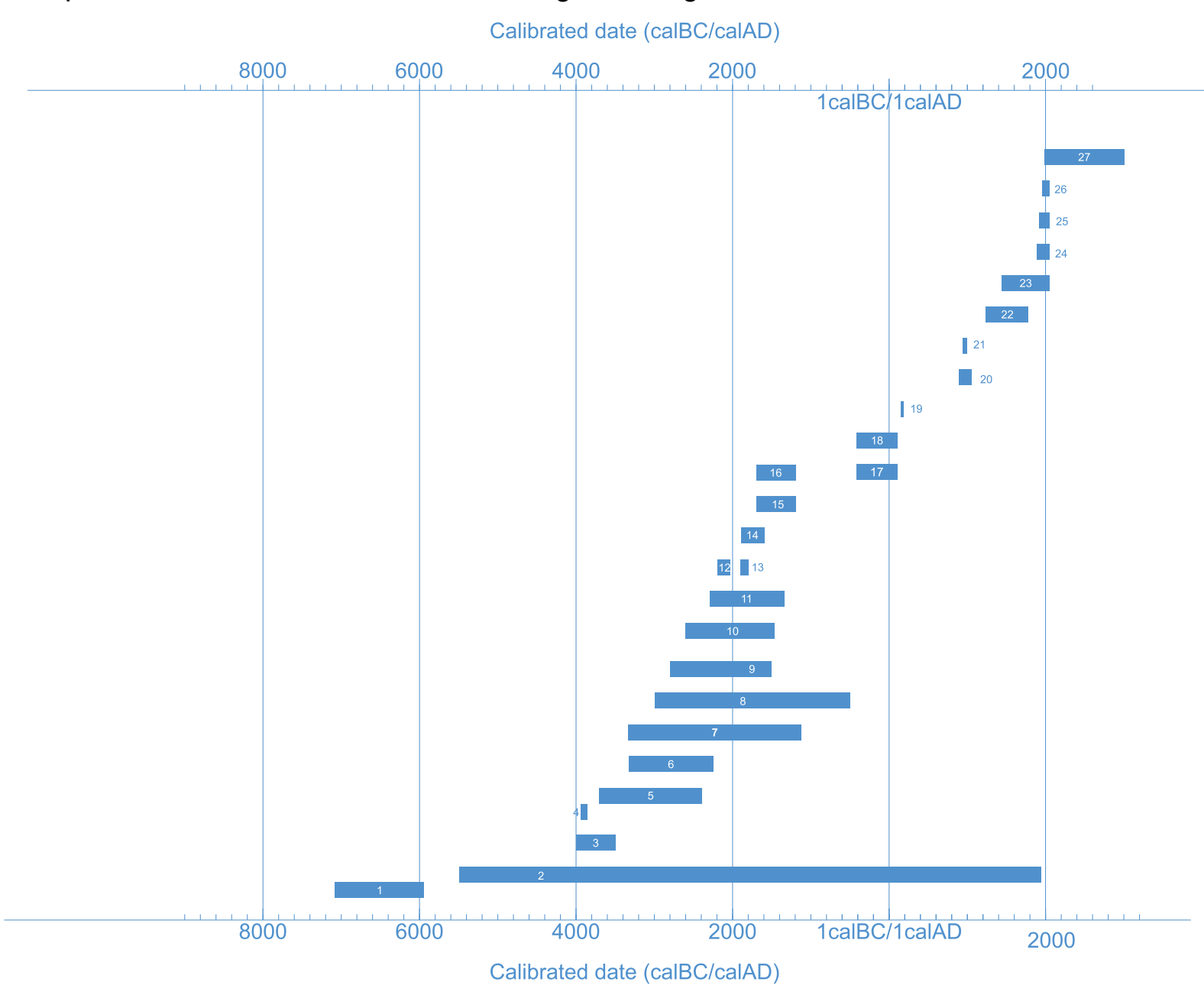

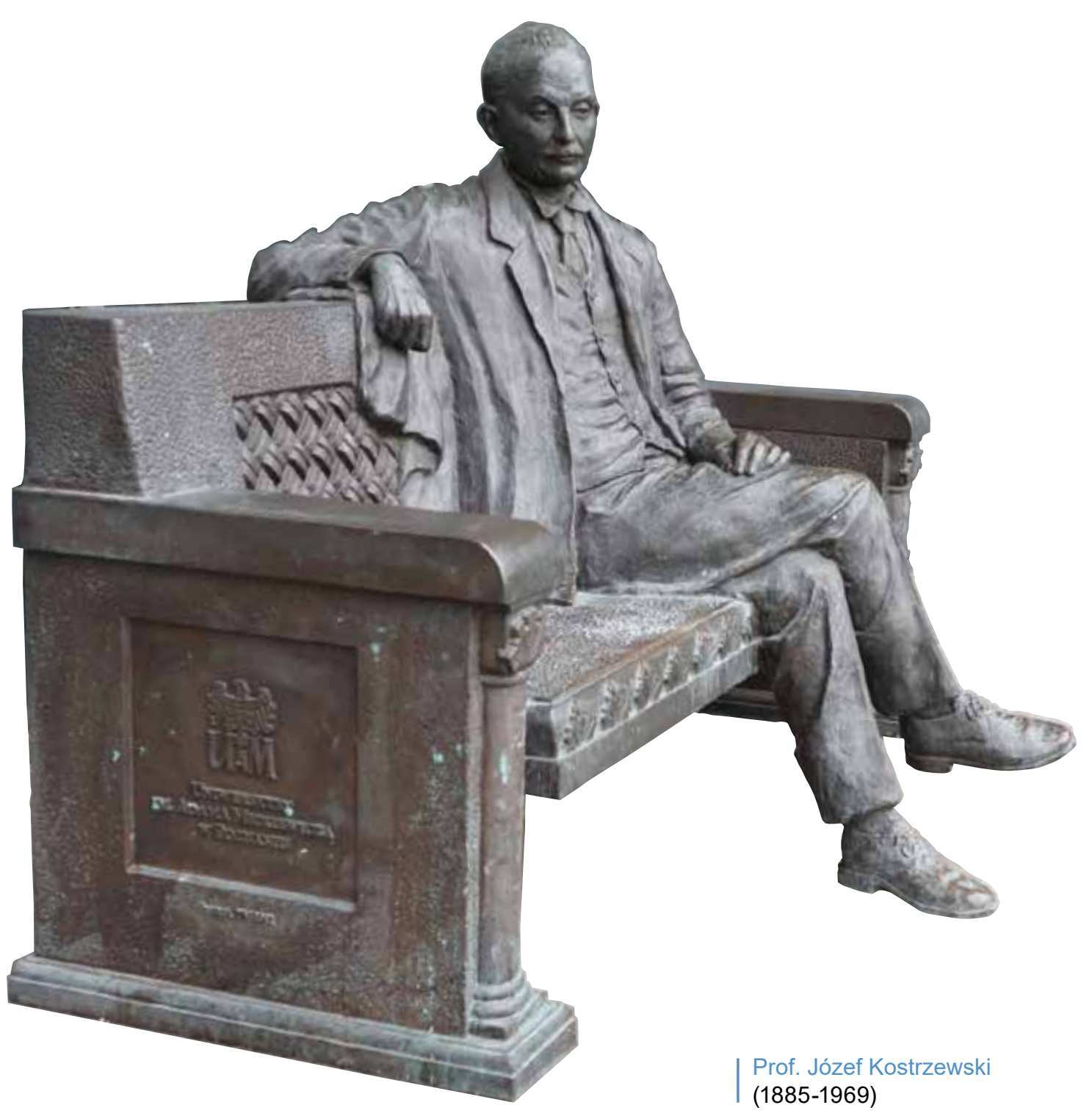

Currently, the Faculty of Archaeology of Adam Mickiewicz University is formed by a number of teams, each with their own leaders. In the majority of cases, these teams are united by interdisciplinarity, which integrates within selected projects the experience of many so-called 'auxiliary' sciences of archaeology. This trend is paralleled by the development of specialised laboratories armed with the latest equipment in the Faculty of Archaeology.

This publication presents the current scientific interests creatively developed by such teams at the Faculty of Archaeology of Adam Mickiewicz University. The research of these teams covers vast areas in time and space, summing up at least the last 9,000 years of prehistory. The following articles, arranged in chronological order, allow us to explore the prehistory of various areas.

The adventure begins around $7100 \mathrm{BC}$, in the Neolithic settlement of Çatalhöyük located in Turkey. Then, we move on to the loess uplands near Krakow, where the first farmers from the south of Europe had just arrived (5500 BC). A little later (4000-3500 BC), and a little farther north, in the area of Greater Poland, some of the first megalithic constructions in this part of the world were built. Around the same time, about $800 \mathrm{~km}$ to the southeast, a settlement 
of the Trypillia culture remains in the phase of development (3950 BC). The end of the Stone Age in Poland was described in the history of Late Neolithic communities on a hill in the center of Kujawy region (3700-2400 BC). Farther east, in the forest-steppe area of Ukraine, significant cultural and social changes resulted in the formation of the Yamnaya culture (3350-2250 BC) beginning the Bronze Age.

Intense elements of this era can be traced in the area of southern Europe in the Greek Anthemous Valley (3350-1150 BC), in Attica (3000-500 BC) on the plains of the Hungarian Lowlands (2600-1450 BC) and to the Upper Dniester Valley, where numerous burial mounds were formed (2800-1500 BC). A similar chronological range is presented in the articles devoted to a unique site in Bruszczewo, Greater Poland (2300-1350 BC), which not only accumulates valuable metal artefacts, but is also the subject of interest of an interdisciplinary team focused on reconstructing its environmental context.

The next text take us far to the east, to the area of Iraqi Kurdistan, where we can appreciate the importance of Mesopotamian influences in shaping the picture of the Early Bronze Age (2200-2150 BC).

Subsequent texts describe the discoveries of Poznań scientists in Syria (1906-1787 BC) and in Greater Poland (1900-1600 BC). These two distant points describe various aspects of life in contemporary communities in the Middle and Early Bronze Age.

The characteristic archaeological materials of the later centuries of the Bronze Age (1800-1200 BC) reveal an intensification of military conflicts and migration processes $(1700-1200 \mathrm{BC})$. The turn of the eras is illustrated in this volume by texts on the interpretation of representations on ancient Greek and Roman sculpture (400 BC-100 AD), as well as the cultural situation in the Polish lands (400 BC-100 AD).

We are introduced to the new era by an article on the funerary customs of communities from the Polish lowlands describing discoveries at the site of Mirosław (160-175 AD). Moments of the formation of elements of Polish statehood are referred to in texts describing towns at Grzybowo (919-1050 AD) and Poznań in the early Middle Ages (950-1000 AD).

Later parts of the Middle Ages are described by sacral monuments located also in the area of the contemporary city of Poznań: the Collegiate Church of St Mary Magdalene (1263-1802 AD) and the still extant Church of the Blessed Virgin Mary on Ostrów Tumski, founded around $1431 \mathrm{AD}$ in the immediate vicinity of the previously described early medieval site of the 'origin' of the city of Poznan.

The final texts of the volume do not refer directly to a particular period of prehistory, but present the history of Polish archaeological research on the Iberian Peninsula, the contemporary perception of prehistoric art by the inhabitants of present-day Canada and Siberia, and the development of methodological thought among Poznań archaeologists.

The volume closes with a text describing one of the many perspectives currently faced by the staff of the Faculty of Archaeology of Adam Mickiewicz University in Poznań: the new ArchaeoMicroLab.
We look to the future with great hope that the Staff of the Faculty will provide ideas for many more volumes of Treasures of Time. We trust that this set of articles will present archaeology at the Adam Mickiewicz University in Poznan in its new structure as a Faculty and show its potential. We would thus like to encourage you to get acquainted with our Poznań perspective on archaeological studies, and to reflect on ways of exploring the past.

\section{Andrzej Michałowski}

Danuta Żurkiewicz
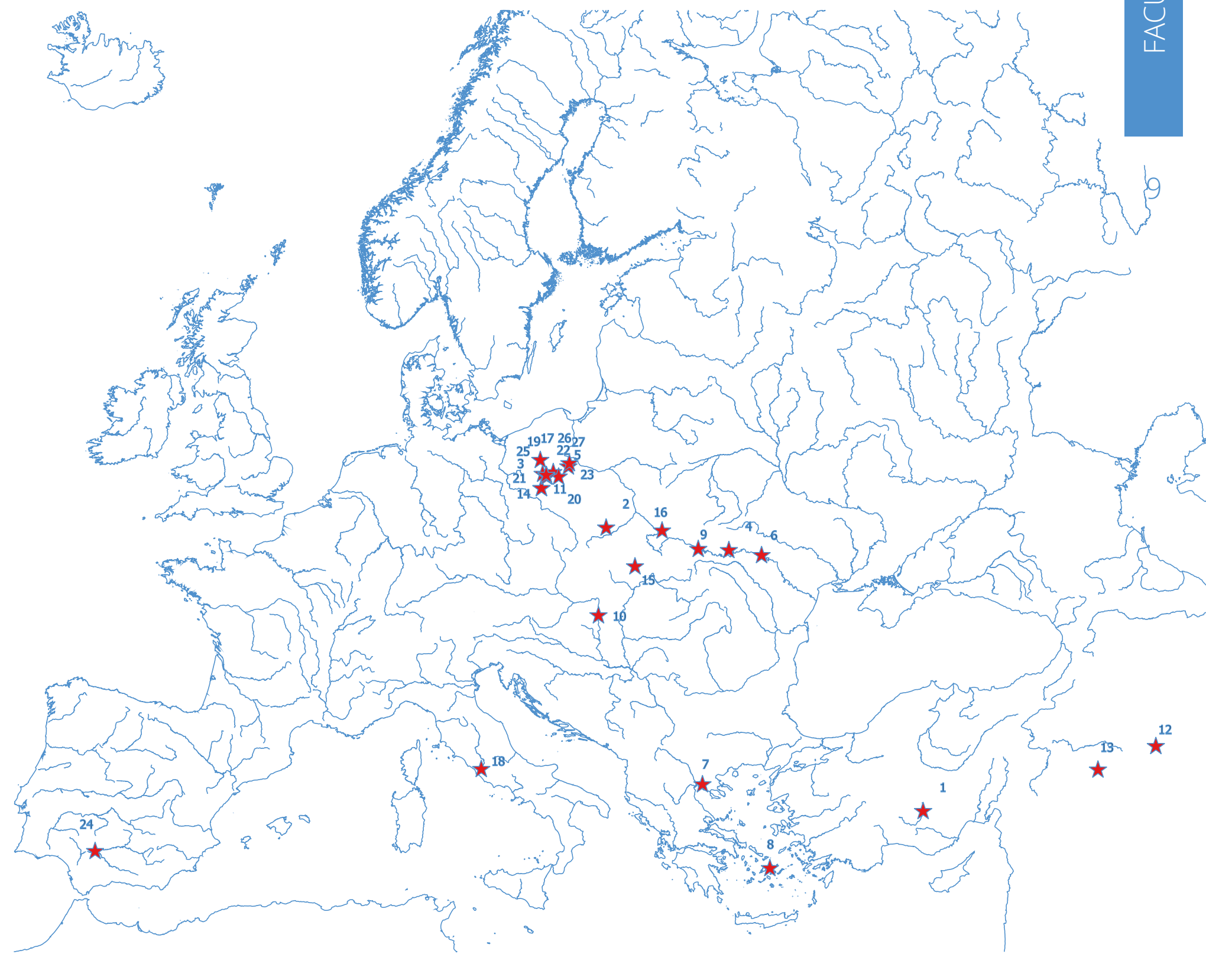

Numbering, compare the table of Contents. 
Treasures of Time:

Research of the Faculty of Archaeology of Adam Mickiewicz University in Poznań

DOI 10.14746/WA.2021.27.978-83-946591-9-6

Are we where we wanted to be?

Modernist tendencies versus the postmodern reality of archaeology.

Some remarks on the methodology of archaeologists

at Adam Mickiewicz University in Poznań

Danuta Minta-Tworzowska

Abstract

This article attempts to define the place where the Poznan University's methodology of archaeology finds itself. The question contained in the title - a are we where we wanted to be? - requires an answer that considers the extent to which the modernist assumptions of archaeology, in which we grew up, have been fulfilled, and to what extent we function in the postmodern world. The article presents the rationale for this methodology, showing some variation in the views of its representatives, starting with the founder of the school, Jan Żak, through his students to the next generation. Recognizing the polyphonic nature of this scholarship, an attempt was made to group these studies into specific issues, which are: reflection on the methodology and theory of archaeology; its inspirations and proposals; relations between theory, methods, and practice; issues of archaeological sources as ones reflecting methodological discussions in the diachronic approach; the past explored in the present; emerging fields of research such as landscape studies; and social archaeology, initiated at Adam Mickiewicz University with the work of Ciesielska on social theory. For many years, the concept of social archaeozoology has also been developed, and studies on memory, identity, children and childhood, among others, have been conducted. The broadening of research fields is an unquestionable achievement of the postmodern (post-processual) as well as post-postmodern reorientation, marking the world in which we function.

\section{7-2021 AD}




\section{Introduction}

This article is an attempt to give an answer concerning the main features of the methodology and theory of archaeologists from Adam Mickiewicz University (AMU) in Poznań. It is most difficult to make such a diagnosis internally (cf. an attempt at such a diagnosis: MintaTworzowska \& Pawleta, 2013). Therefore, some inspiration in this regard was an external diagnosis in the form of an article by Henryk Mamzer from 2020 entitled "»Mowa obrończa" metodologii archeologów Uniwersytetu im. Adam Mickiewicza w Poznaniu [Defence Speech: Methodology of Archaeologists of Adam Mickiewicz University]", in which the author outlined the main directions of research of these archaeologists, dealing with the discussed subject matter as fundamental in their scientific research (Mamzer, 2020, pp. 110-148)'. The use of the metaphor "defence speech" is telling, but it is about presenting the rationale of this methodology and not the colloquial understanding of defence. Mamzer tried to integrate the different, polyphonic views into a certain whole, which gives a broader view of the issue. Knowing the research temperament of Mamzer, it is not difficult to guess that his considerations were deepened by a wide philosophical and anthropological reflection, in the context of which he outlined the elements of this methodology.

This article is more relational in nature, although it does not shy away from the necessary reflection. The set of issues that can be identified are primarily the methodology and theory of archaeology, the issues of archaeological sources, and the past in the present.

Methodology and theory of archaeology - internal inspirations (methodological Poznan school) "supported" by external (particularly Anglo-Saxon) inspirations Methodology of archaeology

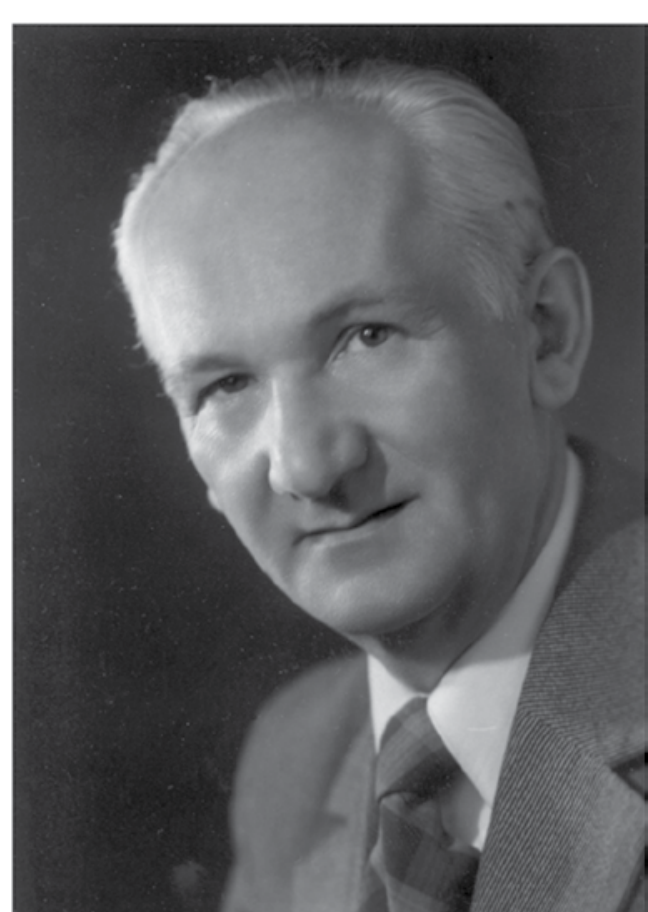

The work of archaeology methodologists at AMU is characterized by the above mentioned diversity, but concerns the reflection on archaeological theory and methodology initiated by Jan Żak in his efforts to go beyond the positivist (i.e, inductionist, experimental) model of archaeological knowledge (Żak \& MintaTworzowska, 1987) (Figures 1, 2). In this respect, the academic archaeology of Poznan represented one of the few centres in Poland developing this subject. Professor Żak researched subjects archaeology addressed in the 1970 s and 1980s, namely the ethnogenesis of the Slavs, their settlement, and especially their continuation/discontinuation (Żak, 1985; 1985a ). He was also interested in the identity of archaeology and its place among other

Figure 1. Professor Jan Żak, 1976 (Photo: Franciszek Lachowicz).

As H. Mamzer pointed out, this is an expanded version of that delivered in 2019 , for the $100^{\text {th }}$ anniversary of archaeology at Adam Mickiewicz University in Poznań.

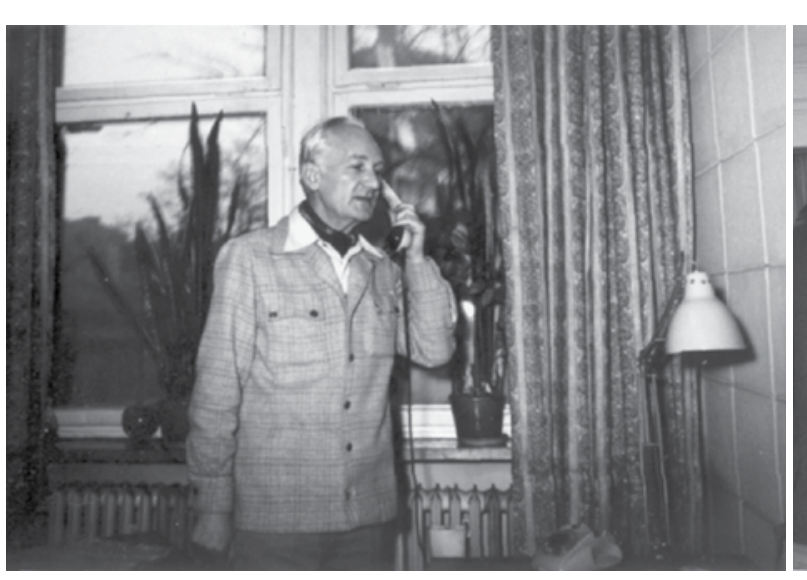

Figure 2. Professor Jan Żak in the office at Collegium Novum - 1978 (private archive)

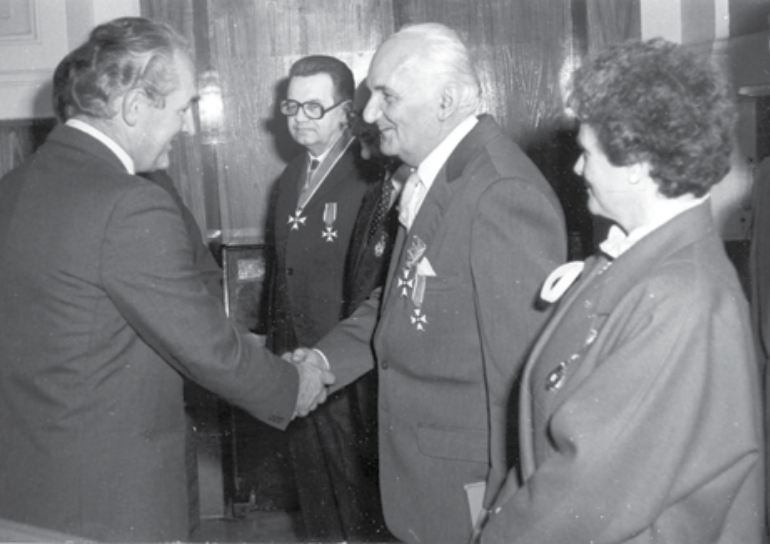

Figure 3. Professor Jan Żak receives the Order of Polonia Restituta - October 14, 1978 (private chive). humanities (Żak, 1966, pp. 69-75), as well as the reflection of prehistoric people - a perspective with which he was ahead of his time (Żak, 1974/1975) (Figure 3). Applying the humanistic interpretation, he noticed fundamental differences in the thinking and perception of the world by prehistoric and modern people, showing how internal contradictions led to changes. $\mathrm{He}$ viewed consciousness as a reflection of the conditions of human life and as a regulator of this life. Thus, consciousness in Żak's view means knowledge, magic, religion, and ancestral-triba ideology. In this way, he not only built a model of human reflection, but he accomplished part of this idea; he created a model of consciousness of Palaeolithic societies of the Mediterranean zone, describing it as naive-naturalistic (Żak, 1974/75). Thereby, he demonstrated a different model of practicing archaeology.

Professor Żak's students, and then the next generation of researchers, tried to seek an answer to the question asked recently and explicitly by Mamzer (2020) - why do we need the methodology and theory of archaeology? Representatives of academic archaeology have tried to show the indispensability of the theory of archaeology; referring in the 1980s to our indigenous theories (e.g., what the methodological school of Poznan offered), linked to the idea of archaeology as a historical science, and later, from the 1990s and especially after 2000 , to broader solutions borrowed from world science (e.g., Minta-Tworzowska, 2017).

The output of AMU archaeologists, which was noticeable, as it were, from the very beginning gets divided into two different methodological stances (humanistic and one with a natural science inclination), although both were shaped as part of the methodological school of Poznań, created by Jerzy Kmita, Leszek Nowak, and on the grounds of archaeology - Jerzy Topolski. The supporters of these new archaeological views were Jan Żak ${ }^{2}$ in the Poznan centre and Stanisław Tabaczyński in Warsaw (Figure 4).

In 1982, Professor Jan Zak established the first and only Department of History and Methodology of Prehistory at a Polish university at the Institute of Prehistory (1982), which ended its formal existence when the Faculty of Archaeology of Adam Mickiewicz University was established (2019) without an internal structure. Its activities ion entitled Archeologia - paradygmat - pamieć (Minta-Tworzowska \& Rączkowski, 2001). 


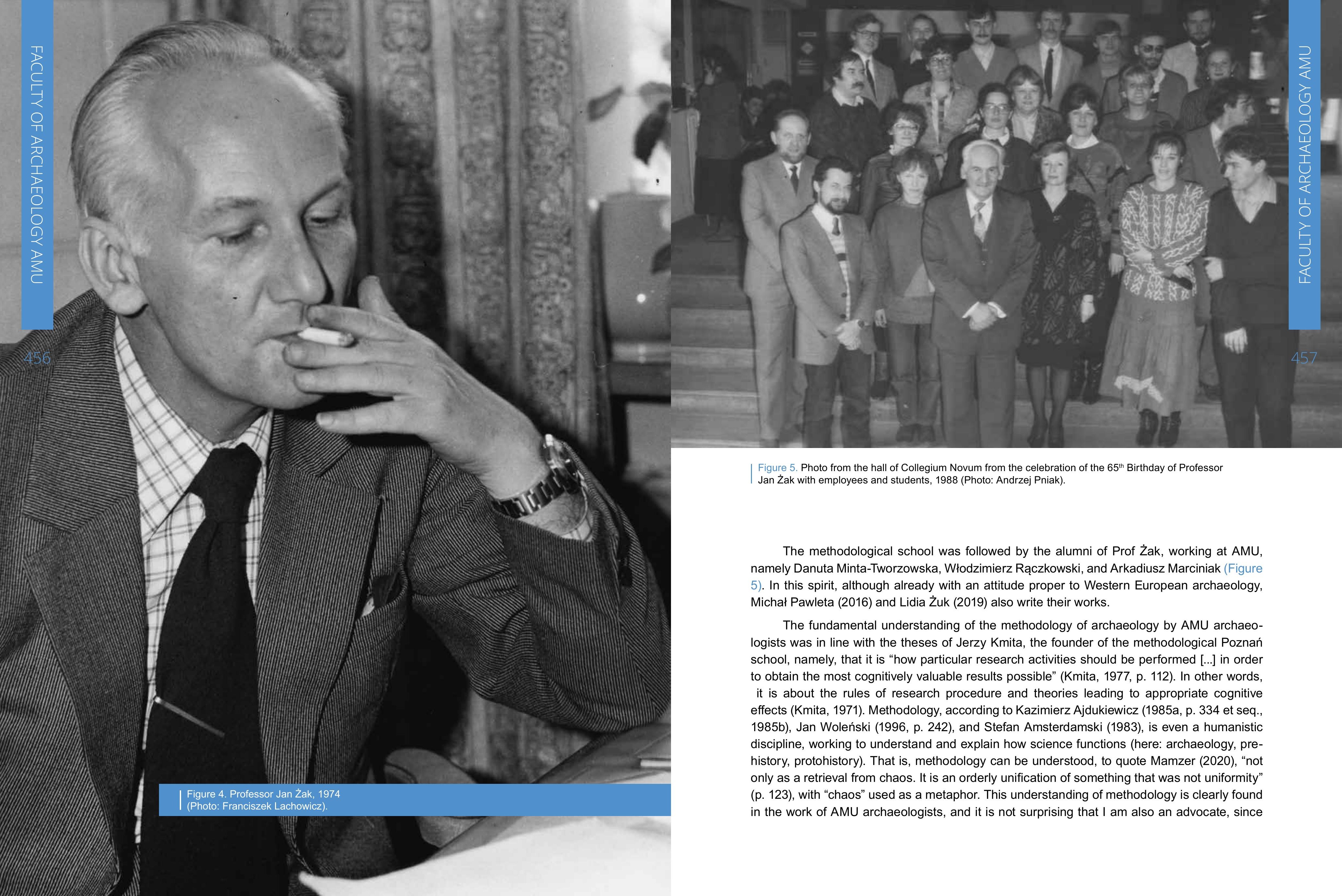


I have studied topics from the role of Pierre Teilhard de Chardin's original historiosophy in building archaeological foundations (Minta-Tworzowska, 1986), to research showing the role of classification and typology in archaeology as a manifestation of assumed theories (Minta-Tworzowska, 1994; 2000a).

Of similar nature are considerations and reflections on the topic of prehistoric and ancient art by Ewa Bugaj (2018) and prehistoric art by Minta-Tworzowska (2018). We put archaeological data, observable in the course of fieldwork as well as subsequent analysis, in order by means of specific terms. We place these data into analytical schemes; that is, we order them in our own way, which may be different from that of other researchers. However, granting the products the character of art and noticing the symbolic aspect, not only in my opinion, testifies to a certain research attitude, especially to the assumption that language and culture play a fundamental role in building images of the world and thinking about it.

Along with the opening of archaeology to the anthropological perspective of practicing it, there was a clear thirst for solutions from world of science (albeit often creative ones), including an inclination towards external inspirations, mainly Anglo-Saxon, sometimes German or French. An example is the monumental volume edited by Stanisław Tabaczyński, Arkadiusz Marciniak, Dorota Cyngot, and Anna Zalewska from 2012 entitled Przeszłość społeczna. Próba konceptualizacji [Social Past: An Attempt at Conceptualisation], in which AMU archaeologists made a significant contribution. The theory of Polish archaeology is seen almost exclusively as one borrowed from the outside, which is probably an oversimplification and not entirely legitimate. Anglo-Saxon archaeology can be seen similarly - it borrows theses from philosophy, cultural anthropology, and other disciplines. Certain ideas have been around for a long time and the activities of philosophers, methodologists, and theoreticians of a given science notice them, "extract" them from the world, name them, and define their place and function.

Without going deeper into the reasons why archaeology (and Polish science as a whole) succumbs to Western pressure, I will refer to the words of Kmita (2015), who wrote "blocking the thinking is conditioned by the permanent association of what is modern with what is "foreign" (pp. 101, 102). Modernity, unfortunately, has determined this unequivocally. Native thought has no chance of legitimizing knowledge, while the "running for points" that excessively promotes works written in foreign languages in foreign journals or publishing houses has determined this definitively and rather for a long time. In very simple terms, let us assume that archaeological research is interdisciplinary. Archaeology is not alone in drawing a variety of inspirations, but it is more about its own theories, which would be developed within archaeology itself, regardless of whether native or external. I have described this relationship elsewhere as a community of inspirations on the one hand, and a distinctiveness of traditions in practicing archaeology on the other (Minta-Tworzowska, 2002). This is why some scholars want archaeology to be the anthropology of prehistory, but anthropology first and only later prehistory (Kowalski, 2015, p. 143), and propose cultural studies archaeology. Others believe that it should be linked to historical sciences, while still others to cultural/social anthropology. This does not change the fact that, for example, lan Hodder (1990-1991) believes that archaeology is simply archaeology.

Personally, I think that scientists' dreams of building "universal" knowledge at the interface of disciplines (e.g., archaeology and nature), which face enormous difficulties, should be tempered. First, there is no universal terminology because of the logical incomparability of the concepts used by various disciplines. The second difficulty is the relative incomparability of stages, phases of development of a given discipline (e.g., the positivist and anti-positivis stages "speak" different languages). Finally, there is also a clear distinction of archaeologists' statements about the past as formulated in the subject language, while ways of reflecting on the past require a distance from that language (they require a metalanguage). I wrote about methodological inspirations of this kind in my work on Pierre Teilhard de Chardin, whose historiosophy determined his views on archaeology, and who created new terms intended to be "universal", linking all knowledge. Also, in subsequent works I continued to express quite consistently the opinion that this was not possible, although from today's perspective it can be very tempting (Minta-Tworzowska, 1986; 1991, p. 234; 2014), which is reflected in a publication with the telling title Współczesne oblicza przeszłości [Contemporary Faces of the Past] (Marciniak et al., 2011).

After 1989, the theory and methodology of Polish archaeology opened up to everything the West offered. I think, however, that the foundations of Kmita's and Topolski's thought have remained, but the issues or considerations currently considered by archaeologists, and which new inspirations open up novel fields of research, have broadened. Anticipating a bit the conclusion, I think that the successive research directions in archaeology first of all have widened its research field, and this is their main merit. However, the specificity of the methodology of Polish archaeology has largely disappeared, as has that of others, due to the phenomena that occurred after 2000. I put it as a dilemma "between the community of inspiration and the distinctiveness of archaeological traditions" (Minta-Tworzowska, 2002).

\section{Theory}

What generally follows from methodological assumptions is assumed theory. Theory can be understood mainly as a way of thinking about the past, although sometimes also as a way of constructing images of the past. It is also noticeable that American and English sciences have been at the forefront of theory and proposing new solutions. I think it is legitimate to refer to Matthew Johnson's thesis that "we are all theorists" (Johnson, 2013, p. 25) and therefore, in his view, there is no need to talk about the necessity of theory because we all use it, whether we are aware of it or not. So then, what is the problem? Some archaeologists "push" this fact out of their consciousness, showing off an anti-theoretical attitude in extreme cases and a reluctant attitude in milder ones. Theoretical standards in Polish archaeology have received much at tention in attempts to diagnose them (Minta-Tworzowska \& Raczkowski 1996; 2007). Following Kmita, and especially Topolski, we assume the primordiality of theoretical knowledge vis-à-vis empirical knowledge, which resounds unambiguously especially in the works of Rączkowski, particularly in Archeologia lotnicza [Aviation Archaeology] (2002), but also in Marciniak (2012a; 2012b; 2012c) and Pawleta (2016). I myself have also written in the spirit of the indispensability and primordiality of theory in any archaeological research, including in relation to the application of classification, or typology (Minta-Tworzowska, 1994, p. 14), and whether contemporary archaeology "needs" theory (Minta-Tworzowska, 2015a) 


\section{Theory versus research method and practice}

A topic that has been tackled in different ways depending on methodological orientation was the relation: theory vs. research method and practice. Noteworthy is the work of Włodzimierz Rączkowski's on theory in archaeologists' practices, which he related to non-invasive methods, especially aerial photography. The scholarship of Rączkowski and his students is mainly oriented towards interpretation, and the article entitled "Interpreting Archaeological Features on the Wieprza River Floodplain, West Pomerania, Poland" (Banaszek \& Rączkowski, 2019) is a meaningful proof of this. Recently, an article by Rączkowski (2017b) entitled "Praktyk badawcze archeologów: kilka refleksji o wykorzystywaniu metod nieinwazyjnych [Archaeological Research Practices: Some Reflections on the Use of Non-invasive Methods] has been published, in which, once again and emphatically, the author indicates what a momentous role methodological foundations play in interdisciplinary research, a role to which the method of aerial photo interpretation pretends to play. The author shows that even opening up to western science has not changed much in Polish archaeology and states that:

without knowledge of the basics of aerial archaeology, it is an activity that does not provide any information that would add anything to the knowledge of the past. In fact, observing common practices related to the use of drones, one can get the impression that the patterns developed in the 1930s are still dominant. The question of the lack of critical reflection remains relevant (Rączkowski, 2017b, p. 330)

The narrative of Rączkowski's subsequent important works on the use of aerial photographs for various landscapes, including historical cities, is built around these relations of theory, method, and practice and argues with the visualisations made based on them (Raczkowski, 2017c, 2020b). The author does not shy away from discourse built around metaphors, which he relates to the relationship between theory, method, and practice in settlement studies or landscape studies. He uses the metaphors of the "anatomy of emptiness" (Kolenda \& Rączkowski, 2018), "river and quagmire" (Rączkowski, 2018), and the "power or misery of visualization" of remote sensing data (Rączkowski, 2020b).

These themes are linked directly to a broader question concerning modes of representation in archaeology (Marciniak, 2012b) and related dilemmas. Practical application was found in these considerations, which, as I mentioned earlier, aimed at combining the humanistic plane with the natural science inclination, as evident in Marciniak's work on research at the Neolithic settlement at Çatalhöyük (Düring \& Marciniak, 2005; Marciniak, 2013; 2015b; Marciniak e al., 2015). The above studies of Neolithic society at a unique archaeological site, combined with the search for theoretical and methodological solutions, allowed that author to develop a model of research in Polish archaeology, which he describes as social zooarchaeology, and constitutes an original scientific achievement (Marciniak, 2005; 2006; 2011; 2015a; Marciniak \& Pollard, 2015; Marciniak \& Tabaczyński, 2017)

Changes in terms of theory are more frequent than one would expect. These will be ilustrated below, using the example of a specific issue that is strongly embedded in the orbit of interest of Poznań University archaeologists, namely the archaeological source/fact.
Problems of archaeological sources

The source as a cultural construct

It seems that all the problems outlined above are focused as if through a lens by the subject matter of methodological considerations concerning the so-called archaeological sources, present in the deliberations of academic archaeologists, especially its humanistic option. The use of the terms source, archaeological source, archaeological record, and archaeological fact is value-laden rather than objective, as archaeological practitioners would like to believe. The latter, heavily tainted by the objectivity of cultural-historical archaeology, would like to approach sources as "hard" facts whose inductive generalisation is supposed to lead to "true knowledge" (i.e., that based on the thesis that only facts exist). One may consider this thesis outdated and refer to the title of Johnson's chapter "Zdrowy rozsadek to za mało" $(2013$, p. 21), a theory is needed. This does not change the fact that archaeological sources, although created by the researcher (Rączkowski, 2002, p. 13) are the essence of archaeology. I devoted my attention to the problem of the archaeologist's interference in the meaning of the source also in the article "Jerzego Topolskiego koncepcji źródeł historycznych a ujęcia źródeł archeologicznych [Jerzy Topolski, the Concept of Historical Sources and the Approach to Archaeological Sources]" (Minta-Tworzowska, 1998), and especially in the text entitled "Człowiek i rzecz w perspektywie archeologicznej, czyli rzecz w perspektywie antropocentrycznej [Man and Thing in the Archaeological Perspective (i.e., the Thing in the Anthropocentric Perspective]" (Minta-Tworzowska, 2011). In them, I point to the unambiguous "entanglement" of material products in our human perception, in our culture, which has shaped certain norms and values. Marciniak takes a slightly different approach to the problem of source material in his book Archeologia i jej źródła. Materiały faunistyczne w praktyce badawczej archeologii [Archaeology and its Sources: Faunal Materials in the Research Practice of Archaeology] (1996), indicating the so-called objectivising planes that define the limits of interpretation proper to the humanities. In any case, on the basis of sources, as Minta-Tworzowska and Pawleta (2013) write, conclusions and interpretations concerning prehistory are made and oriented "here and now" by conceptual schemes, thus having little to do with induction. Therefore, the basic activity of the archaeologist is their ordering, or classification, to which the monograph entitled Klasyfikacja w archeologii jako sposób wyrażania wyników badań, hipotez oraz teorii archeologicznych [Classification in Archaeology as a Way of Expressing the Results of Research, Hypotheses and Archaeological Theories] (Minta-Tworzowska, 1994), among others, is devoted. In addition, it should be borne in mind that classification using the criterion of similarity and difference is also dictated by the valuing modern concept - the idea of progress/regress, or the concept of change. The idea of progress combined with the passage of time thus forms the basic core of the concept of ordering material sources. This is how I see the mechanism of constructing the "reality" of the past, controlled by the nineteenth century idea of nationalism, a "reality" which is not considered to be constructed in research practice. It is then difficult to say that we are dealing here with what results from sources and placing this result over conceptualisation.

The archaeological source, in the view of Rączkowski (2011) as well as myself (Minta-Tworzowska 1998), can be reduced to the cultural character of the source, which is also in line with the views of Kmita and Pałubicka (1992; cf. also Mamzer, 2020). Therefore, a metho- 
dological perspective is all the more important to approach sources and show what they "do not say". Referring to the significant statement of Rączkowski (2011), it should be assumed that "the archaeological source ceased to be the starting point of the research procedure and began to serve the verification/testing of hypotheses. [...] is the result of the archaeologist's decision, giving meaning to the object. It is the archaeologist who brings the source to life" (p. 30). Similar in tone is my thesis that "it is the archaeologist who determines what is an artefact, an ecofact, a source, and what is not. It is he or she who creates the source" (Minta-Tworzowska, 2011, p. 46).

\section{Natural science inclination}

The clearest representative of the natural science inclination among the methodologists of archaeology at AMU is undoubtedly Arkadiusz Marciniak (2005; 2006; 2011). The question arises whether it occurs at the level of methods or the subject of archaeological research. Following his views, he tries to combine the research procedure of humanities with that used in natural sciences (i.e., the assumptions of post-processual archaeology with processual ones). Marciniak tends to combine humanistic archaeology with the so-called "archaeological sciences". It is visible in his work on faunal material (Marciniak, 1996) or those concerning human-animal relations in the Neolithic Age (Marciniak, 2006). Marciniak's aim is to integrate, methodologically and theoretically, archaeology as a science of culture with the archaeological sciences deriving from exact sciences and natural sciences (Marciniak, 1996, p. 33). On the one hand Marciniak tries to weaken the formalism of processualism, and on the other hand, he aims at limiting relativism as the main feature of post-processualism. Sources in this connection take on the character of "data" are largely objective, although in some sense culturally marked (Marciniak, 2013; 2020).

As one might think, this manifests the intention for humanistic analysis to reach an appropriate level, similar to that of the natural sciences. These are rather echoes of the Enlightenment "dream" of combining realism with what culture offers. This continues in the contemporary current of "the return to things", described as the new materialism, or new positivism. It should be noted that contemporary Western European archaeology is strongly united with everything offered by the archaeological sciences, although at the same time it prefers post-structuralism or Peirce's theory of signs when applied to archaeological analyses.

\section{Summary}

In my opinion, it is worth realizing that signs and symbols free themselves and us from the realism of a processual, naturalistically inclined archaeology. Moreover, realism obscures non-utilitarian, symbolic content, far more important in culture than anything else (cf. Mamzer, 2010; 2011; 2020). Therefore, realism gives an inappropriate ("false") image of the world, stripped of the properties of culture. I have tried to capture the most important approaches to archaeological sources and their conceptualisations, seeing in them a kind of "three worlds" - positivist, processual, and post-processual - and recently perhaps a fourth one: post-post-processual.
In my work, I made early references to Peirce's theory of signs in terms of its application to archaeological sources (Minta-Tworzowska, 2000a), which is a consequence of my acceptance of the primacy of "cultural spectacles" in our construction of knowledge (more on this later on). Of course, this is not the only way, although it is "dictated" by contemporary tendencies, as indicated by the works of Rączkowski (2002) and Marciniak (1996), who present their original thoughts on archaeological sources.

Past-presence relationships in the aspect of the modernisation of the world and what comes after modernism

Let me start by saying that, as it seems, we have always been (post) modernists. Why? Once controversial topics, ranging from the fluidity of meanings, through the agency of material culture, essentialism, and so forth, are now fully "tamed" due to archaeologists' awareness of their own functioning within a global, ideologized, heterogeneous, capitalist-economy, multicultura world, shaping our view of how we see and represent the past. And, above all, in the various discourses against exposing and valuing some social groups and marginalising others. This heterogeneity and polyvocality are not just an invention of postmodernism, although in processual archaeology it was assumed, as if in the background, that it might not apply to pre-modern societies, especially prehistoric ones.

We have also come to terms with the thesis that the present gives meaning to the past, because it is in the present that the past is "constructed". The methodologists of AMU are part of the reorientation of thinking, referred to as the "linguistic turn", which is present in the work Archeologia lotnicza. Metoda wobec teorii [Aviation Archaeology: Method Against Theory] by Rączkowski (2011), in which he writes about post-processual change as a new research perspective. My chapter entitled "Kwestia przełomu metodologicznego w prahistorii i archeologi polskiej [The Question of A Methodological Breakthrough in Prehistory and Polish Archaeology]"(Minta-Tworzowska, 2000b) is also of similar significance, as are the articles by Marciniak (2012a; 2012b; 2012c), and the previously cited edited volume by Tabaczyński and colleagues (2012). In my opinion, it is all about "discovering" that the cultural factor (the aforementioned "cultural spectacles"), and not just a cognitive attitude, influence the recognition of whether a given utterance in a given language is true or not (the semantic definition of truth). This idea is clearly brought closer by Mamzer (2020) writing that "[...] a sentence uttered in one language may be false in another" (p. 134)

This is why the work of the AMU archaeology methodologists is oriented towards interpretation. They are deeply convinced that it is important to give sense to the most ancient history, since it cannot be "discovered" because the past reality has passed. For this reason, the perspective of the prehistoric world is not only about experiencing it through objects from the past discovered "here and now", but above all about building a conceptual apparatus, or research procedure, and choosing a narrative language. And for this, a methodology is needed. Thus, the understanding of an archaeological source appears to result from the epistemological perspective (the theory adopted), but also from the perspective of contemporary history and culture (Mamzer, 2000). This is related to Richard Rorty's thesis (1996) that "[t]he world 
does not speak. Only we do" (p. 22). Similarly, facts do not speak, therefore sentences about the past have a value-laden character. Accordingly, a constructivist approach should be adopted by pointing out that the symbolic sphere of these archaeological sources is also important (Minta-Tworzowska, 2011; cf. Marciniak, 2013). Clearly constructivist in nature and oriented towards humanistic interpretation, are the works authored/co-authored by Rączkowski (2018 Banaszek \& Rączkowski, 2020; Kolenda \& Raczkowski, 2018), opting for post-processualism.

The world of post-processual or even post-post-processual archaeology is already taken for granted by Pawleta (2016), Żuk (2019), and a whole group of the younger generation of archaeologists fascinated by the theory and methodology of archaeology in its different varieties. This is expressed in their completed PhD theses, and some in their habilitation theses, among which of note are kukasz Banaszek, Adriana Ciesielska, Mariusz Drzewiecki, Patrycja Filipowicz, Maksymilian Frąckowiak, Paweł Kasper Hanus, Anna Jankowiak, Grzegorz Kiarszys, Dawid Kobiałka, Mikołaj Kostyrko, Przemysław Krajewski, Magdalena Matczak, Paweł Polkowski, Michał Sołtysiak, Rafał Zapłata and a number of others.

And I think it is not about the obvious variability of views on archaeology and the role of theory and research methodology, but about the context that surrounds us, as a kind of "frame". We experience the world through relationships between things, in a particular time and space, and the human being is only one of these entities. In this sense, this external contex shapes the vision of tasks, goals, and possibilities for us as archaeologists. By contrast, the "spectacles" of our culture make our view of reality subjective, shaped by human mentality. They depend on our views, but we can only use them within a certain "framework". Assuming that modernism has shaped us, this would be the "spectacles"; however, the present reality in which we function is this "framework", shaped by relations between people and things, "trimming" our modernist hopes of, for example, the existence of objective truth, but opening us up to other, new possibilities and fields of research.

Moreover, it may still be possible to convince oneself that processual archaeology is one that seeks "truth"; however, post-processual archaeology it is much more difficult, as it is diverse, multi-voiced, and therefore incoherent. It does not contain, like a "toolbox", ready-touse solutions, and one instead has to work hard to create such tools on their own. This is not to say that processual archaeology offers "simple" solutions. Lewis Binford or David Clarke themselves wrote works with complex solutions, not trying to simplify archaeological issues by force and instead did quite the opposite (Binford, 1978; Clarke, 1968). In the 1980s and 1990s, a debate about processualism swept through archaeology, especially regarding what was coming up as a reaction to it, offering the relativism that was feared most. In archaeology, postmodernism was combined with post-processual archaeology (Bintliff, 1991; Hodder, 1990; 1991; Shanks \& Tilley, 1992; Urban \& Schortman, 2012; and in Poland: Marciniak, 2012a; MintaTworzowska, 2000c; Rączkowski, 2011), although this relativism loomed large even in the minds of the proponents of change, who had some concerns whether it would not lead them one step too far.

The postmodern reorientation, as it is defined by Anna Pałubicka (2018) among others, seems to favour five basic themes in contemporary archaeology: (a) the relativisation of truth, knowledge, and meaning; (b) the fragmentation of grand narrative; (c) the relationship between agency and discourse; (d) pluralism, polyphony, and heterogeneity; and (e) different rhetoric and writing styles. Above all, it broadens the field of research to further include new or previously marginalised topics.

A particular work that addresses the issues of contemporary times (those that I describe as post-processual and post-post-processual) is Pawleta's original 2016 work Przeszłość we współczesności. Studium metodologiczne archeologicznie kreowane przeszłości w przestrzen społecznej [The Past in the Present: A Methodological Study of the Archaeological History Created in Social Space]. In it, the author unequivocally advocates the idea of the past as "belonging" to the present. Hence, this work redefines the place of archaeology today in the era of creating images of the past not only for other archaeologists, but for a wide social audience. The past, including the prehistoric past, is not only perceived, but made present and experienced. And historical culture as a key to this understanding also allows us to understand contemporary phenomena such as reconstructions, exhibitions, and archaeological festivals. Mamzer (2020) refers to Pawleta's formulation of "the past in the present" as "counteracting the forgetting of tragic past events [...]" (footnote 14). Pawleta's work also takes into account the extremely positive values that the past has passed on to the present. It is the past that matters for contemporary times, even such distant ones as those of prehistoric or early medieval periods.

An important place in this aspect, but also as a research field, is occupied by critical reflection on the management of archaeological heritage, especially its dissemination and publicisation. Finding invigorating inspiration in what is referred to as public and community archaeology (Pawleta, 2020), it seeks to identify the fields where the importance of archaeology, its role in the creation of social identities, and the need to protect archaeological heritage or to raise awareness about the need for community participation in this task can be highlighted. Starting from the recognition of the key role of the presentation and interpretation of heritage sites in the context of their protection and conservation, it refers to issues such as full-scale archaeological reconstructions, archaeological festivals, historical re-enactments, archaeological museums, archaeological tourism or the commercialisation of archaeology, and archaeological knowledge (Pawleta, 2019). These elements, with the right balance between accessibility and preservation in line with the paradigm of sustainable development, undoubtedly have an impact on highlighting the social utility of archaeology. This is contained in responding to socio-cultural demands for the images of the past it creates, social expectations of the discipline, as well as archaeology's ability to respond to the challenges of the modern world and participate in social dialogue (Marciniak et al., 2018; Pawleta, 2017; 2019; 2020).

Another new research field that has opened up with post-processualism in archaeology is the discourse of memory. The considerations of Żuk $(2015 ; 2019)$ concerning the relation of the archaeological landscape (understood as a palimpsest) to memory, are part of this. The author referred in her study of memory in general to the work of the German archaeologist and historian Jan Assmann, and especially to his predecessor Maurice Halbwasch. In line with Assmann, she identified memory with cultural transmission, aimed at preserving cultural continuity through the transmission of a specific body of knowledge from one generation to the next (Assmann, 2008; Ingold, 2003). Żuk focuses on how the actualising role of memory, social memory, and commemorative processes are relevant to the research practice of archaeology as connecting to the materiality of memory sites. Linking monuments with memory is a result of the author's assumption that by constructing permanent forms (prehistoric) communities expressed a desire to permanently transform space and inscribe in it the meanings important 
for it in a way that imposes interpretation on subsequent generations (Żuk, 2015; 2019). I have also devoted some attention to the issue of memory in the context of archaeology, especially its "social record" and the construction of "sediments" of identity in the form of graves, or rather ancient cemeteries (Minta-Tworzowska, 2013; 2015b). Above all, however, Pawleta (2015) has written in a similar vein as Żuk, but with reference to stone circles in Pomerania as "places of memory".

The study of the category of the child and childhood, initiated within the framework of post-processual studies in archaeology, is also an important strand of the developed interests. It is still a relatively new issue in Polish archaeology, possessing, however, quite a large heuristic potential. The issues addressed include a reflection on the reasons for the marginalisation of this issue in archaeology to date. As a consequence of the imputation of certain anachronisms surrounding the child and childhood, contemporary images of the child and childhood have been unreflectively translated by archaeologists into the past, resulting in dated depictions that obscure the active role of children in the past or their proper place in the life of past societies (Pawleta, 2004; 2009; 2013).

\section{Attempting to answer the question posed}

Given what has been written so far, the answer to the question of whether we are where we wanted to be - and more importantly, whether we are still there - in terms of the methodology and theory of archaeology, turns out to be ambiguous, unless we answer that we have always been post-modernists. By doing so, we would deny the modernist dream of "real" knowledge. It can be argued that reality is dynamic and that there is no fixed point in it where the world could stop and where it would make sense to attempt such an answer. However, every diagnosis requires that we stop for a moment, or at least pay more attention than usual "to something", and in this sense an attempt can be made to answer the above question. It sounds natural, but it is stretched between the modernist dream of scientific truth and the postmodernist, far-reaching reflection of that dream. Therefore, despite its apparent obviousness, the answer is not simple, although we are aware that we are not "out there" in the ordered world of modernist science. The present dilemmas of knowledge are much more difficult to solve.

Archaeological concerns about post-processualism, especially regarding relativism, resulted in the fact that in 2009-2011 some archaeologists began observing clear symptoms of another turn, that of "post-postmodernism". In archaeology, this takes the form of an ontological turn towards things in the form of post-humanist materialism (Olsen, 2013; Olsen et al., 2012), and which finds particular expression in the idea of the so-called symmetrical archaeology (Minta-Tworzowska, 2020), but also in neo-Darwinism. Bjørnar Olsen, on the basis of "the return to things" or in "defence of things", attributes agency to things. He postulates that the focus should no longer be on how people use material objects, but on how they enable people to do so because of their properties and affordances (Olsen, 2013; Olsen et al., 2012).

Is this return to things a return/retreat of archaeology to the times of positivism, albeit in a "new" version devoid of anthropocentrism? Or is it a chance to turn away from everything Western? It is also not difficult to notice the significant differences between the representatives of the turn towards things and the AUM archaeologists who follow them: some perceive them in a network of connections and entanglements, others in categories of material agency, while still others in categories of ontologies of objects. Therefore, the question to be addressed is whether the radicalism of postmodernism (i.e., this sometimes-extreme relativism) is challenged in the new interest in materiality (Minta-Tworzowska, 2020). Postmodernism regards considerations of meaning as relative, while new materialism sees them as the result of entanglement in networks of relations between people and things (Fahlander, 2012). In retrospect, it is quite apparent that each of the theoretical turns in archaeology broadened its field of research, rather than being an explicit negation of previous theories or methodologies. This is also how I see the methodology at AUM - it was first modernized under the influence of the Poznan methodological school of Kmita and Topolski $(1978 ; 1998)$ and, to a lesser extent, Nowak, especially with regard to the intersubjectivisation of knowledge, to move from its ideas to the post-processual stage. So, by what has post-processualism expanded this field? Mainly, as it seems, by social themes and the social functions of archaeology - in particular the five themes cited above - but above all by the complex issues of archaeological heritage and the role of the past in the present, as emphatically demonstrated by Pawleta (2016)

By contrast, almost everyone agrees that contemporary archaeology is less concerned with positioning individual archaeologists in processual, post-processual, or post-post-processual terms, and more concerned with issues that have emerged from modernity, such as agency, neomaterialism, archaeological heritage, providing theory to fieldwork, post-colonialism, feminism, and so forth. This does not change the fact that the postmodern critique in archaeology has stimulated it to reflect anew, to look for solutions, but certainly already in a "post-Latour" world that describes the prehistoric in terms of "redistribution", the reassembly of the social, but in terms of "rhizome", "entanglement", in proliferating "networks" between artefacts, landscapes and people. Although the undeniable problem is that the world in constan becoming and the cardinal question is: can anything be captured within it as a case study? As Fahlander (2012) writes, the "death" of postmodernism is exaggerated and postmodernism is doing well, and some postulates of post-postmodernism can be treated as an intergenerational discussion. This by no means changes the fact that it is the result of a postmodern discussion, even if we cannot exactly define it. To avoid certain pitfalls, archaeologists have addressed theoretical issues, the history of archaeological thought, heritage management, contemporary museum education, and archaeological practice. 


\section{References}

Ajdukiewicz, K. (1985a). Obraz świata i aparatura pojęciowa. In K. Ajdukiewicz (Ed.), Język i poznanie, t. 1 Wybór pism z lat 1920-1939 (pp. 175-195). Warszawa: PWN

Ajdukiewicz, K. (1985b). Systemy aksjomatyczne z metodologicznego punktu widzenia. In K. Ajdukiewicz (Ed.), Język i poznanie, t. 2: Wybór pism z lat 1945-1963 (pp. 332-343). Warszawa: PWN.

Amsterdamski, S. (1983). Między historią a metodą. Spory o racjonalność nauki. Warszawa: PWN.

Assmann, J. (2008). Pamięć kulturowa. Pismo, zapamiętywanie i polityczna tożsamość w cywilizacjach starożytnych. Warszawa: Wydawnictwo UW.

Banaszek, Ł., \& Rączkowski, W. (2019). Interpreting Archaeological Features on the Wieprza Floodplain West Pomerania, Poland. In D. G. Hadjimitsis, K. Themistocleous, B. Cuca, A. Agapiou, V. Lysandrou, R. Lasaponara, \& N. Masini (Eds.), Remote Sensing for Archaeology and Cultural Landscapes: Best Practices and Perspectives Across Europe and the Middle East (pp. 203-220). Cham: Springer.

Binford, L. (1978). Nunamiut Ethnoarchaeology. New York: Academic Press.

Bintliff, J. (1991). Post-Modernism, Rhetoric and Scholasticism at TAG: The Current State of British Archaeological Theory. Antiquity, 65, 274-278.

Bugaj, E. (2018). Badania ikonograficzno-ikonologiczne greckiego malarstwa wazowego - zarys

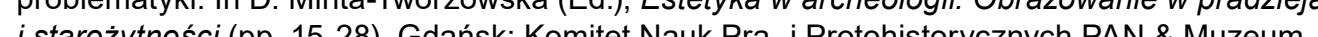
Archeologiczne w Gdańsku.

Ciesielska, A. (2002). Elementy teorii społecznej w archeologii. Koncepcje grup, instytucji i struktur spolecznych. Poznań: Wydawnictwo Uniwersytetu im. Adama Mickiewicza,

Wydział Pedagogiczno-Artystyczny

Clarke, D. (1968). Analytical Archaeology. London: Methuen.

Düring, B.S., \& Marciniak, A. (2005). Households and communities in the central Anatolian Neolithic Archaeological Dialogues, 12(2), 165-187.

Fahlander, F. (2012). Are we they yet? Archaeology and the postmodern in the new millennium, Current Swedish Archaeology, 20, 109-129.

Hodder, I. (1990). Archaeology and the Post-Modern. Anthropology Today, 6(5), 13-15 Hodder, I. (1991). Postprocessual Archaeology and the Current Debate. In R. Preucel (Ed.), Processual and Postprocessual Archaeologies: Multiple Ways of Knowing the Past (pp. 30-41). Carbondale: Center for Archaeological Investigations, Southern.

Ingold, T. (2003). Kultura i postrzeganie środowiska. In M. Kempny, \& E. Nowicka (Eds.), Badanie kultury: Elementy teorii antropologicznej (pp. 73-88). Warszawa: Wydawnictwo Naukowe PWN.

Johnson, M. (2013). Teoria archeologii. Wprowadzenie. Kraków: Wydawnictwo UJ.

Kmita, J. (1971). Z metodologicznych problemów interpretacji humanistycznej. Warszawa: PWN. Kmita, J. (1977). Wykłady z logiki i metodologii nauk dla studentów wydziałów humanistycznych. Warszawa: PWN.

Kmita, J. (2015). Czarnoksięstwa humanistów. Poznań: Fundacja Instytut im. Jerzego Kmity.

Kmita, J., \& Pałubicka, A. (1992). Problem użyteczności pojęcia doświadczenia. In J. Such (Ed.), Poszukiwanie pewności i jego postmodernistyczna dyskwalifikacja (pp. 150-181). Poznań: Wydawnictwo

Kolenda, J., \& Rączkowski W. (2018). Anatomia pustki: o archeologicznym rekonesansie lotniczym w północno-wschodniej części Dolnego Śląska. Przegląd Archeologiczny, 66, 283-318.
Kowalski, A. P. (2015). Antropologia zamierzchłych znaczeń. Toruń: Chronos/Anthropos.

Mamzer, H. (2000). Kulturowe konteksty „paradygmatów” w archeologii. In M. Kobusiewicz, \& S. Kurnatowsk (Eds.), Archeologia i prahistoria polska w ostatnim półwieczu (pp. 537-550). Poznań: PTPN.

Mamzer, H. (2010). Żródła archeologiczne: Artefakty czy językowe o nich wypowiedzi?. Humanistyka i Przyrodoznawstwo, 16, 227-250

Mamzer, H. (2011). Czy możliwe jest materialne (fizykalne) przedstawianie przeszłości?. In W. Wrzosek (Ed.) Oblicza przeszłości (pp. 251-263). Bydgoszcz: Oficyna Wydawnicza Epigram.

Mamzer, H. (2020). Mowa obrończa metodologii archeologów Uniwersytetu im. Adama Mickiewicza w Poznaniu. Folia Praehistorica Posnaniensia, 25, 109-148.

Marciniak, A. (1996). Archeologia i jej żródła. Materiały faunistyczne w praktyce badawczej archeologii. Poznań, Warszawa: PWN.

Marciniak, A. (2005). Placing Animals in the Neolithic: Social Zooarchaeology of Prehistoric Farming Communities. London: UCL Press.

Marciniak, A. (2006). From animals and food in space to bones in context. Social zooarchaeology of the Neolithic farming communities. In D. Papaconstantinou (Ed.), Deconstructing Context: A Critical Approach to Archaeological Practice (pp. 34-49). Oxford: Oxbow.

Marciniak, A. (2011). The Secondary Products Revolution: Empirical evidence and its current zooarchaeological critique. Journal of World Prehistory, 24(2-3), 117-130.

Marciniak, A. (2012a). Paradygmaty badawcze w archeologii. In S. Tabaczyński, A. Marciniak, D. Cyngot \& A. Zalewska (Eds.), Przeszłość społeczna: Próba konceptualizacji (pp. 29-83). Poznań: Wydawnictwo Poznańskie.

Marciniak, A. (2012b). Przedstawianie i narratywizm w archeologii. In S. Tabaczyński, A. Marciniak, D. Cyngo \& A. Zalewska (Eds.), Przeszłość społeczna: Próba konceptualizacji (pp. 162-177). Poznań: Wydawnictwo Poznańskie.

Marciniak, A. (2012c). Teoria w archeologiii. In S. Tabaczyński, A. Marciniak, D. Cyngot \& A. Zalewska (Eds.), Przeszłość społeczna: Próba konceptualizacji (pp. 84-116). Poznań: Wydawnictwo Poznańskie.

Marciniak, A. (2013). Byki, uczty i kozioł ofiarny. René Girard i jego uczniowie w Çatalhöyük. Rocznik Antropologii Historii, 3(2), 169-184.

Marciniak, A. (2015a). Mainstream and minority archaeologies. The case of the beginnings of the Polish bioarchaeology. In K. Kristiansen, L. Šmejda, \& J. Turek (Eds.), Paradigm Found: Archaeological
Theory - Present, Past and Future. Essays in Honour of Evžen Neustupny (pp. 137-146). Oxford: Oxbow.

Marciniak, A. (2015b). Śmierć, grób i zmarły w tworzeniu i przekształcaniu systemów religijnych w neolicie Bliskiego Wschodu. Przypadek osady w Çatalhöyük. In W. Dzieduszycki, \& J. Wrzesiński (Eds.), Funeral Stowarzyszenie Naukowe Archeologów Polskich, Oddział w Poznaniu.

Marciniak, A. (2020). Od śmierci do życia. Archeologia wobec ograniczeń antropologii fizycznej. In J. Goszczyńska, H. Machajewski, A. Skrzeczyńska, \& M. Błazejewska (Eds.), Archeologia miejsc \& Stowarzyszenie Naukowe Archeologów Polskich Oddział Wielkopolski.

Marciniak, A., Asouti, E., Doherty C., \& Henton, E. (2015). The Nature of Household in the Upper Levels at Catalhöyük: Smaller More Dispersed, and More Independent Acquisition, Production, and Consumption Unit In I. Hodder, \& A. Marciniak (Eds.), Assembling Çatalhöyük (pp. 151-165). Leeds: Maney Publishing. Marciniak, A., Minta-Tworzowska, D., \& Pawleta, M. (Eds.). (2011). Współczesne oblicza przeszłości. Poznań: Wydawnictwo Poznańskie. 
Marciniak, A., Pawleta, M., \& Kajda, K. (Eds.). (2018). Dziedzictwo we współczesnym świecie. Kultura, natura, człowiek. Kraków: Universitas. Meillassoux,

Marciniak, A., \& Pollard, J. (2015). Animals and social relations. In C. Fowler, J. Harding, \& D. Hofmann (Eds.) Marciniak, A., \& Pollard, . (2olithic Europe (pp. 745-759). Oxford: Oxford University Press.
The Oxford Handbook of Neolitis

Marciniak, A., \& Tabaczyński, S. (2017). Geneza i rozwój nierówności społecznych w paradygmatach badawczych archeologii: Zarys problematyki. Przegląd Archeologiczny, 65, 45-52.

Minta-Tworzowska, D. (1986). Elementy metodologii prahistorii w historiozofii Teilharda de Chardin. Poznań: Wydawnictwo UAM.

Minta-Tworzowska, D. (1991). Ujęcie nauki w historiozofii P. Teilharda de Chardin. Studia Metodologiczne, 26 221-236.

Minta-Tworzowska, D. (1994). Klasyfikacja w archeologii jako sposób wyrażania wyników badań, hipotez oraz teorii archeologicznych. Poznań: Wydawnictwo Naukowe UAM.

Minta-Tworzowska, D. (1998). Jerzego Topolskiego koncepcja źródeł historycznych a ujęcia źródeł archeologicznych. In W. Wrzosek (Ed.), Świat historii: Prace z metodologii historii i historii historiografii dedykowane Jerzemu Topolskiemu z okazji siedemdziesięciolecia urodzin (pp. 329-340). Poznań: Wydawnictwo Instytutu

Minta-Tworzowska, D. (2000a). Contemporary Debates in Archaeology: The Example of Classification - Part 1. Nova Revista de Historia da Arte e Arqueologia, 3, 218-224.

Minta-Tworzowska, D. (2000b). Kwestia przełomu metodologicznego w prahistorii i w archeologii polskiej. In M. Kobusiewicz, \& S. Kurnatowski (Eds.), Archeologia i prahistoria polska w ostatnim półwieczu (pp. 527-535). Poznań: Wydawnictwo PTPN.

Minta-Tworzowska, D. (2000c). Postmodernizm, myśl poststrukturalistyczna a archeologia (zarys problematyki). In A. Buko, \& P. Urbanczyk (Eds.), Archeologia w teorii i praktyce (pp. 87-95). Warszawa: Komite Nauk Pra- i Protohistorycznych PAN, IAE PAN.

Minta-Tworzowska, D. (2000d). Świat archeologii w świetle źródeł archeologicznych. Acta Historica et Museologica Universitatis Silesianae Opaviensis, 5, 49-59.

Minta-Tworzowska, D. (2002). Between a community of inspiration and the separatennes od archaeological traditions. In P. F. Biehl, A. Gramsch, \& A. Marciniak (Eds.), Archäologien Europas. Geschichte, Methoden

und Theorien [Archaeologies of Europe: History, Methods and Theories] (pp 53-64). Münster: Waxmann.

Minta-Tworzowska, D. (2011). Człowiek i rzecz w perspektywie archeologicznej, czyli rzecz w perspektyprzeszłości (pp. 39-61). Poznań: Wydawnictwo Poznańskie.

Minta-Tworzowska, D. (2013). Pamięć, miejsca pamięci jako budujące tożsamość w ujęciu archeologii. Przegląd Archeologiczny, 61, 1-15.

Minta-Tworzowska, D. (2014). Teilhard de Chardin po latach. In F. Lenort, \& J. Szpet (Eds.), De Catechizandis Adultus: Opuscula Romualdo Niparko septuagenario dedicata (pp. 181-190). Poznań: Wydawnictwo Naukowe UAM.

Minta-Tworzowska, D. (2015a). Czy współczesna i przyszła archeologią będą „potrzebowały” teorii. Archeologia Polski, 60, 21-37.

Minta-Tworzowska, D. (2015b). O „użyteczności” rozważań nad miejscami i krajobrazami pamięci w archeologii. In B. Gediga, A. Grossman, \& W. Piotrowski (Eds.), Miejsca pamieci: Pradzieje, średniowiecze
i współczesność (pp. 13-30). Biskupin, Wroctaw: Muzeum Archeologiczne w Biskupinie \& IAiE PAN. Minta-Tworzowska, D. (2017). Tradycja i inspiracje teoretyczne we współczesnej archeologii. Filo-Sofija, 36, 267-285.
Minta-Tworzowska, D. (2018). Elementy "nowej" estetyki a wspołczesna archeologia. In D. Minta-Tworzowska (Ed.), Estetyzacja w archeologii: Obrazowanie w pradziejach i starożytności (pp. 71-80).

ologiczne w Gdańsku.

Minta-Tworzowska, D. (2020). W jaki sposób myśl splata się z rzeczami w archeologicznych sposobach prezentacji pradziejowego świata. Przykład ,archeologii symetrycznej”. In B. Gediga, \& Sz. Nowaczyk (Eds.),
Od archeologii przedmiotów do archeologii idei (pp.1-30 ). Biskupin-Wrocław: Komisja Archeologiczna PAN \& Muzeum Archeologiczne w Biskupinie.

Minta-Tworzowska, D., \& Pawleta, M. (2013). Teoria i metodologia archeologii na Uniwersytecie w Poznaniu. Folia Praehistorica Posnaniensia, 18, 217-233.

Minta-Tworzowska, D., \& Rączkowski, W. (1996). Theoretical Traditions in Contemporary Polish Archaeology. World Archaeological Bulletin, 8, 196-209.

Minta-Tworzowska, D., \& Rączkowski, W. (Eds.). (2001). Archeologia - paradygmat - pamięć Poznań: Wydawnictwo Poznańskie.

Minta-Tworzowska, D., \& Rączkowski, W. (2007). Standardy teoretyczne we współczesnej polskiej archeologii. In J. Lech (Ed.), Poł wieku z dziejöw archeologiii polskiej (1939-1989) (pp. 219-247).

\section{Warszawa: PWN.}

Olsen, B. (2013). W obronie rzeczy: Ontologia i archeologia przedmiotów. Warszawa: Instytut Badań Literackich PAN.

Olsen, B., Shanks, M., Webmoor, T., \& Witmore, C. (2012). Archaeology: The Discipline of Things. Berkeley - Los Angeles - London: University of California.

Pałubicka, A. (2018). Ponowoczesność i humanistyka. In D. Minta-Tworzowska (Ed.), Estetyzacja w archeologii: Obrazowanie w pradziejach i starożytności (pp. 71-80). Gdańsk: Muzeum Archeologiczne.

Pawleta, M. (2004). Re-Constructing Childhood in Archaeology. Ethnographisch-Archäologische Zeitschrift, 44(2/3), 181-198.

Pawleta, M. (2009). Archeologia dzieciństwa. Sprawozdania Archeologiczne, 61, 9-38.

Pawleta, M. (2013). An Archaeology of Childhood - A New Subfield of Study. In P. Romanowicz (Ed.) Child and Childhood in the Light of Archaeology (pp. 9-28). Wrocław: Wydawnicto Chronicon.

Pawleta, M. (2015). Kręgi kamienne na Pomorzu w koncepcii „,miejsc pamięci”. In B. Gediga, A. Grossman \& W. Piotrowski (Eds.), Miejsca pamięci: Pradzieje, średniowiecze i współczesność (pp. 385-414).

Biskupin - Wrocław: Muzeum Archeologiczne w Biskupinie \& IAiE PAN.

Pawleta, M. (2016). Przeszłość we wspótczesności. Studium metodologiczne archeologicznie kreowanej przeszłości w przestrzeni społecznej. Poznań: Wydawnictwo Naukowe UAM.

Pawleta, M. (2017). Theatrum Archaeologicum: Staging the Past via Archaeological Fêtes and Historical Reenactment. Sprawozdania Archeologiczne, 69, 33-53.

Pawleta, M. (2019). Archaeotourism Spaces in Present-day Poland: Thoughts on Reconstruction and Reenactments. In D.C. Comer \& A. Willems (Eds), Feasible Management of Archaeological Heritage Sites Open to Tourism (pp. 115-127). Cham: Springer.

Pawleta, M. (2020). Archeologia odpowiedzialna społecznie. Działania z zakresu public i community archaeology w Polsce. Folia Praehistorica Posnaniensia, 25, 169-190.

Rączkowski, W. (1996). Drang nach Westen? Polish Archaeology and National Identity. In M. Diaz-Andreu, \& T. Champion (Eds.), Nationalism and Archaeology in Europe (pp. 189-217). London: UCL Press.

Rączkowski, W. (2002). Archeologia lotnicza - metoda wobec teorii. Poznań: Wydawnictwo Naukowe UAM 
Rączkowski, W. (2011). Teoria, empiria i praktyka. Archeologiczne dyskursy w sieci zależności i opozycji. Acta Archaeologica Resoviensia, 4, 23-34

Rączkowski, W. (2017a). Historyczne przestrzenie miasta we współczesnym kontekście- $z$ dystansu. In W. Rączkowski, \& J. Sroka (Eds.), Historia i kultura ziemi sławieńskiej, tom 12 (pp. 261-286). Sławno: Fundacja Dziedzictwo.

Rączkowski, W. (2017b). Praktyki badawcze archeologów: kilka refleksji o wykorzystaniu metod nieinwazyjnych. In A. Różański (Ed.), Gemma Gemmarum. Studia dedykowane Profesor Hannie Kóćce-Krenz (pp. 323-342). Poznani: PTPN \& WH UAM.

Rączkowski, W. (2017c). Zdjęcia lotnicze badań wykopaliskowych w Biskupinie - w stronę efektywne interpretacji. Sprawozdania Biskupińskie, 5, 9-16.

Raczkowski, W. (2018). O rzece i grzęzawisku. In H. Machajewski (Ed.), Archeologia dawnego osadnictwa Wielkopolski (pp. 11-30). Poznań: WKZ \& SNAP.

Rączkowski, W. (2020a) Historische Ladschaften aus der Perspective der Fernerkundung. In O. Kühne T. Strobel, R. Traba, \& M. Wiatr (Eds.), Kulturlandschaften in Deutschland und Polen (pp. 133-152). Göttingen: V\&R unipress.

Raczkowski, W. (2020b). Power and/or Penury of Visualizations: Some Thoughts on Remote Sensing Data and Products in Archaeology. Remote Sensing, 12, 1-23.

Rorty, R. (1996). Przygodność, ironia i solidarność. Warszawa: Wydawnictwo Spacja.

Shanks, M., \& Tilley, C. (1992). Re-Constructing Archaeology: Theory and Practice. Cambridge: Cambridge University Press.

Tabaczyński, S., Marciniak, A., Cyngot, D., \& Zalewska, A. (Eds.). (2012). Przeszłość społeczna. Próba konceptualizacji. Poznań: Wydawnictwo Poznańskie.

Topolski, J. (1978). Rozumienie historii. Warszawa: PIW.

Topolski, J. (1998). Wprowadzenie do historii. Poznań: Wydawnictwo Poznańskie.

Urban, P. A., \& Schortman, E. (2012). Archaeological Theory in Practice. Walnut Creek, CA: Left Coast Press. Woleński, J. (1996). W stronę logiki. Kraków: Aureus.

Żak, J. (1966). Historia pierwotna i jej współczesne metody. Studia Metodologiczne, 2, 67-89.

Żak, J. (1974/1975). Próba przedmiotowego modelu kultury społeczeństw młodszego i schyłkowego paleolitu (strefy śródziemnomorskiej). Fontes Archaeologici Posnanienses, 25, 28-59.

Żak, J. (1985a).O kontynuacji/dyskontynuacji społecznej i kulturowej na ziemiach nadodrzańskich

i nadwiślańskich w V-V/VI wieku n.e. Folia Praehistorica Posnaniensia, 1, 85-105.

Żak, J. (1985b). Uwagi metodologiczne nad problemem osadnictwa. Studia Metodologiczne, 24, 77-87. Żak, J., \& Minta-Tworzowska, D. (1987). Problematyka prahistorii pozytywistycznej. Folia Praehistorica Posnaniensia, 4, 9-25

Żuk, L. (2015). Rzeczywistości pamięci społeczności pradziejowych. In B. Gediga, A. Grossman \&W. Piotrowski (Eds.), Miejsca pamięci. Pradzieje, średniowiecze i współczesność (pp. 79-110).

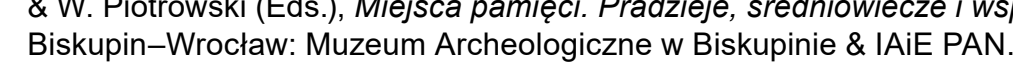

Żuk, L. (2019). Pamięć o krajobrazie jako kategoria analizy archeologicznej. Poznań: Unpublished typescript stored in the AMU Faculty of Archaeology.

\section{Author:}

Danuta Minta-Tworzowska, Faculty of Archaeology, Adam Mickiewicz University, Uniwersytetu Poznańskiego 7, 61-614 Poznań, Poland.

ORCID: 0000-0003-3330-625, e-mail: danminta@amu.edu.pI 
27. Archaeology under a microscope: research at ArchaeoMicroLab of the Faculty of Archaeology Adam Mickiewicz University in Poznań

26. Are we where we wanted to be? Modernist tendencies versus the postmodern reality Some remarks on the methodology of archaeologists at Adam Mickiewicz University in Poznań

25. Rock art as a source of contemporary cultural identity: a Siberian-Canadian Comparative Study

24. Polish archaeological research in the Iberian Peninsula

23. Archaeological research of the Gothic Church of the Blessed Virgin Mary on the island of Ostrów Tumski, Poznań

22. Research on Kolegiacki Square in Poznań (St. Mary Magdalene Parish Collegiate Church)

21. | Poznan in the early Middle Ages

20. The stronghold in Grzybowo and its settlement base in the context of in-depth interdisciplinary research

19. | Barrows in the Skirts of the Forest. Excavation of a Wielbark culture cemetery at Mirosław 37, Ujście commune, Piła district, Greater Poland Voivodeship

18. Some Remarks on the Problems of Art Research in Archaeology using the Example of Greek and Roman Sculpture

17. About the 'interim' or discovering the depths of the pre-Roman Iron Age

16. Migration and kinship in East-Central Europe in the $1^{\text {tst }}$ half of the $2^{\text {nd }}$ millennium $B C$

15. Aspects of ancient warfare: Multidisciplinary research on war and warriors in Bronze Age Europe

Metallurgy in the Early Bronze defensive settlement in Bruszczewo, site 5, Śmigiel commune,Kościan district. One more step on the way to the synthesis

13. I From the cradle to the grave

12. From clay you are

11. When archaeology meets environmental sciences: the Bruszczewo site revisited

3. Lost and found: The Funnel Beaker culture's 'megalithic tombs' in the cultural and natural landscape of Greater Poland

Heritage regained: results of rescue excavations in the Land of Cracow 
ISBN 978-83-946591-9-6 